serve as a model of how to handle criticisms and errors.

Who should buy which book? Anyone studying birds will want both books. They are long, crammed with information, and a bargain for the price. Anyone concerned with relationships within a group other than birds will at least want to study Sibley and Monroe, as a model of what taxonomy can achieve. The Sibley and Ahlquist book is for anyone in molecular evolution and evolutionary biology, for many other types of biologists, and for anyone (including historians) interested in how to do and present landmark science.

Jared M. Diamond is at the University of California Medical School, Los Angeles, California 90024, USA.

\section{Classical agriculture}

\section{Paul Halstead}

The Ecology of the Ancient Greek World. By Robert Sallares. Duckworth/ Cornell University Press: 1991. Pp.588. $£ 42, \$ 84$.

UNLIKE prehistorians, who readily pillage the natural sciences for insights in to the material record of the human past, ancient historians prefer the more familiar and superficially more tangible testimony of ancient texts. In The Ecology of the Ancient Greek World, Robert Sallares aims to cast some muchneeded, multidisciplinary light on this dim recess of academia by writing "the first comprehensive ecological history of the ancient Greek world".

That Sallares transcends contemporary disciplinary parochialism is beyond dispute - detailed philological and historiographical argument competes for space with wideranging forays into archaeology, anthropology and evolutionary biology and ecology. With 800 footnotes and 2,000 bibliographic entries, The Ecology of the Ancient Greek World is unquestionably a serious work of scholarship, but never dull. Sallares has opinions on the irrationality of vegetarianism, the evolution of concealed ovulation in humans and the evolutionary prospects for AIDS. He explains the nature of causality and, in a scathing but witty assault on the traditional classical scholar, advocates comparative research as the historian's equivalent of the experimental method in science. He dismisses M. Finley, G. de Ste. Croix, M. Weber, K. Marx and F. Braudel on early Mediterranean towns, repeatedly admonishes 'New Archaeologists' for invasion-phobia, effectively demolishes E. Boserup's model of agricultural development and, at rather greater length, rewrites the evolutionary history of wheat. The historian is brought up to date on the extinction of dinosaurs, history of bubonic plague and Dutch elm disease; ecologists should enjoy the pioneering work of Hegesandros on island biogeography.

Sallares defines ecology somewhat narrowly as the study of "the distribution and abundance of populations of living organisms in relation to their environment" and of "rates of flow of energy between different levels of food chains". Accordingly, the core of the book deals at length with the demographic and agricultural history of Greece during the first millennium BC. Recent evidence from intensive archaeological surveys, which has revealed drastic and widespread fluctuations in site numbers is taken to indicate equally drastic fluctuations in human population density. The problems of variable 'visibility' of different chronological horizons and of evident alternation between nucleated and dispersed settlement are acknowledged but then ignored - Sallares is, throughout, least convincing in his handling of archaeological evidence.

More particularly, he follows A. Snodgrass in arguing that increasing numbers of burials during the early first millennium $\mathrm{BC}$ mark a steep rise in population; he perceptively criticizes but fails to refute T. Morris' suggestion that this trend reflects archaeologically visible burial of an increasing proportion of the population. A lengthy digression on skeletal evidence for the age and sex structure of the population is far too inconclusive to clarify changes in population size. More intriguing is the proposition that early Greek society in the first millennium $\mathrm{BC}$ was characterized by a system of age-class organ-

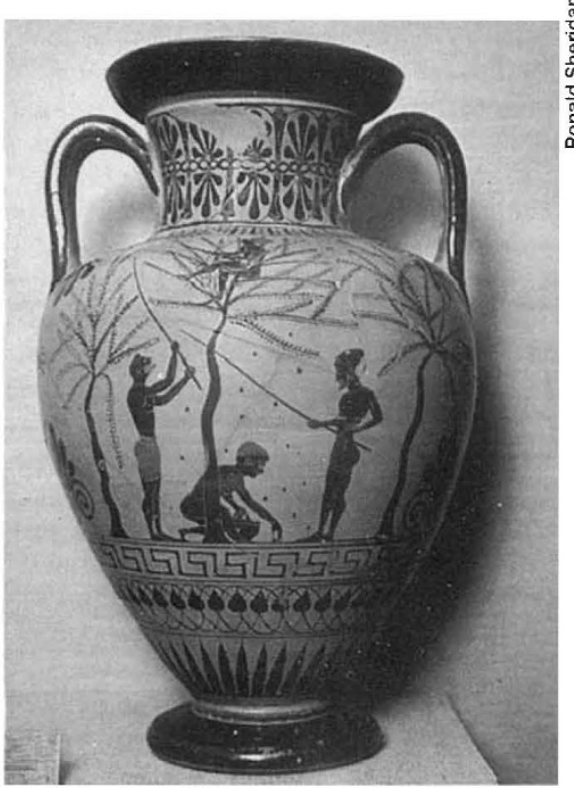

Images of nature - vase depicting olive harvester from the fourth century Bc.

ization, which served to restrain population growth by delaying marriage for males (delayed marriage for females would have been more effective). Sallares seems to demolish his own case, however, by arguing that in Attica the age-class system was falling into disuse at a time when population growth was slowing down.

On agriculture, Sallares makes perceptive comments on the ecological and economic context of recent farming practices, and on the dangers of uncritical extrapolation from present to past. Ultimately, however, his arguments on the nature and scale of classical land use are sloppy, failing to draw a clear distinction between what was ecologically or technologically possible, what would have been economically viable or 'rational' and what may be implied by scarce historical and archaeological evidence. The unorthodox claim that classical Athens was basically selfsufficient in staple grains is probably correct, but hardly substantiated. Even more unjustified is the assertion that the steep rise in human population during the first millennium $B C$ was made possible by significant improvements in agriculture. Sallares justly criticizes the traditional emphasis on improvements in agricultural technology, but his claim that the displacement of glume wheats by free-threshing wheats reflects the improved productivity of the latter is quite unsubstantiated. Even if classical archaeologists bothered to collect charred crop remains, grain size is affected by interannual and local variation in growing conditions, by crop-cleaning methods and by charring regime, and is only indirectly related to area yield. Given that naked wheats had remained in cultivation on a small scale for millennia throughout Europe, their ultimate displacement of the more storable but troublesome glume wheats surely reflects a shift of emphasis in risk-buffering behaviour from local self-sufficiency and storage to regional integration and exchange. Furthermore, the assumption that classical civilization was underpinned by surplus resulting from higher-yielding crops reflects the same misplaced faith in progress which Sallares effectively condemns in earlier works. In fact, in an area of high agricultural risk such as southern Greece, a 'normal surplus' will have been an inevitable by-product of any viable farming economy and an investigation of changes in access to land, labour and produce would probably have been far more illuminating.

Despite these criticisms, The Ecology of the Ancient Greek World is informative and thought-provoking. Sallares' inability to leave any intellectual stone unturned does nothing for the clarity of his argument, but it also makes him eminently readable and his evident enthusiasm for history and ecology is very engaging. This unusual book, with its blend of references to scientific papers from the first millennium $\mathrm{BC}$ and $1980 \mathrm{~s} \mathrm{AD}$, will interest a wide readership. For ancient historians, to whom it is primarily addressed, it should be compulsory reading and those not yet beyond redemption will learn much from the experience.

Paul Halstead is in the Department of Archaeology and Prehistory, Sheffield University, Sheffield S1O 2TN, UK. 